\title{
NIPPON ECONOMIC THINKING DURING THE SHOGUNATE PERIOD
}

\author{
Marius-Ioan MIHUȚ ${ }^{\mathrm{a} *}$ \\ a) Babeș-Bolyai University, Faculty of Economics and Business Administration, \\ Cluj-Napoca, Romania
}

Please cite this article as:

Article History:

Mihuț, M.I., 2019. Nippon economic thinking during the Shogunate period. Review of Economic Studies and Research Virgil Madgearu, 12(2), pp.109-119.

doi: 10.24193/RVM.2019.12.43.

Abstract: The main objective pursued within the research is presenting the Shogunate period from the perspective of economic thinking, how the economical components were approached and analysed during the Shogunate period, to emphasise the importance of this period on Japanese economic thinking overall. The aspects presented showed that the vast majority of the ideas expressed by the representatives of this period indicated that during the Shogunate a series of values were founded, such as long work, restraint, acceptance of the hierarchy, acceptance of the authority, high savings, endless ambition, awareness of the group's power, caring for the subjects' good. All these, combined with the critical economic doctrines, through their nipponisation, led to the strengthening of the Nippon economic doctrine.

Key words: economic thinking; Shogunate; Japan; theories; doctrines JEL Classification: B15; B22; B3O

(C) 2019 Alma Mater Publishing House. All rights reserved.

* Corresponding author. E-mail address: marius.mihut@econ.ubbcluj.ro. 


\section{References:}

1. Crawcour, E.S., 1963. Changes in Japanese Commerce in the Tokugawa Period. The Journal of Asian Studies, 22 (4), pp.387-400.

2. Gramlich-Oka, B. and Smits, G.J., 2010. Economic Thought in Early Modern Japan. Boston: Brill, pp.89-111.

3. Mosk, C., 2012. Economic Thought in Early Modern Japan. The Journal of Japanese Studies, 38(1), pp.258-261.

4. Najita, T., 1997. Visions of Virtue in Tokugawa Japan: The Kaitokud? Merchant Academy of Osaka: University of Hawaii Press.

5. Najita, T., 2009. Ordinary economies in Japan: a historical perspective, 1750-1950 (Vol. 18). Univ of California Press.

6. Ravina, M., 1998. Land and lordship in early modern Japan. Stanford University Press.

7. Roberts, L.S., 2002. Mercantilism in a Japanese domain: The merchant origins of economic nationalism in 18th-century Tosa. Cambridge University Press.

8. Saito, O., 2005. Pre-Modern Economic Growth Revisited: Japan and The West, Working Paper No. 16/o5, London School of Economics.

9. Suzuki, T.M., 2005. History of Japanese Economic Thought. London: Routledge.

10. Tuiu, F., 1987. Niponism. Teorie și actiune. București: Politica.

11. Walthall, A., 1999. The Perception of Work in Tokugawa Japan: A Study of Ishida Baigan and Ninomiya Sontoku. The Journal of Japanese Studies, 25(1), pp.189-193.

12. Ye, L. and Qian, L., 2014. Research on the Development of Rural Commodity Economy in the Edo Period. Asian Agricultural Research, 6(12), pp.1-8. 